\title{
Does The Mix Of A State's Tax Portfolio Matter? An Empirical Analysis Of United States Tax Portfolios And The Relationship To Levels And Growth In Real Per Capita Gross State Product
}

Bruce Howard (E-mail: bruce.howard@wheaton.edu), Wheaton College

\begin{abstract}
An important part of the economic environment for any business is the tax climate. At the federal level, arguments are often made for abandoning the income tax in favor of a national sales tax or other type of tax. At the state level, the United States has a laboratory of sorts for examining the economic impact of various types of taxes. The states exhibit a wide degree of variation in the kinds and mix of taxes upon which they rely to raise revenue. This provides an opportunity for comparing economic well-being with the mix of taxes for the various states. This paper presents the results of an empirical study of the relationship between the relative economic well-being of a state and its relative portfolio of taxation. Data on the kinds and relative mix of taxes for the 50 United States for the years 1993-1999 are summarized. While the direction of causation is still an issue, the results of the study show that statistically significant relationships do exist between a state's tax portfolio and its level and growth of real per capita gross state product. Hopefully this study will add to our understanding of the impact of taxation on the economic climate for business.
\end{abstract}

\section{Introduction}

Taxing Questions

hat makes a good tax? The question is age old and enduring. It was addressed at some length by Adam Smith in The Wealth of Nations. He began his examination of the subject by setting forth the four following maxims:

1. The subjects of every state ought to contribute towards the support of the government, as nearly as possible, in proportion to their respective abilities; that is, in proportion to the revenue which they respectively enjoy under the protection of the state.

2. The tax which each individual is bound to pay ought to be certain, and not arbitrary.

3. Every tax ought to be levied at the time, or in the manner, in which it is most likely to be convenient for the contributor to pay it.

4. Every tax ought to be so contrived as both to take out and to keep out of the pockets of the people as little as possible, over and above what it brings into the public treasury of the state. (Book IV, chapter II, part II)

Smith's maxims contain both the notions of fairness and efficiency. Equity and economic efficiency continue to be standards by which we today judge the "goodness" of a tax.

Readers with comments or questions are encouraged to contact the author via email. 
This article presents the findings of an empirical study of the comparative tax regimes of the 50 United States and the possible impact on economic well-being of the states. The issue of equity is important but lies outside the scope of this investigation. This study focuses on the relative mix of taxation at the state and local level for the 50 states to see if there is reason to believe that states are economically any better or worse off by virtue of the strategy of taxation that has been adopted by the state.

In 1999, per capita real gross state product ranged from a low of $\$ 21,617$ in West Virginia to a high of $\$ 44,263$ for Connecticut. The average for all 50 states was $\$ 31,356$. The annual growth in per capita real GSP also varied considerably in 1999 with the state of Idaho leading growth at a rate of $7.4 \%$ and Delaware experiencing the lowest growth declining .7\%. The average growth of per capita real GSP in 1999 was 3.4\% for all 50 states. The 50 states exhibit a remarkable range of variation in the degree to which they rely on various taxes to raise revenue. It is both an interesting and important exercise to see if a statistically significant relationship can be detected between the mix of taxes and economic well-being.

\section{The Issue}

The states rely principally on three types of tax to raise revenue. They use property taxes, consumption taxes and income taxes. Property taxes can include both real and personal property. Consumption taxes can be levied specifically on excised goods like cigarettes, liquor and motor fuels, or they can levied more broadly on retail sales. They can also target purchases of consumables used in a trade or business, in which case they are called use taxes. Income taxes can be levied on income attributed to individuals, to groups of individuals in partnerships, or on corporate income. While these represent the main forms of taxation, states also employ, to a much lesser extent, other taxes such as franchise/wealth taxes and licenses/permits.

All of these taxes introduce an element of market distortion and potential inefficiencies that impact economic welfare. Taxing individual income has both an income effect and a substitution effect that combine to influence the work-leisure tradeoff. Taxing an individual's income lowers the return and incentive to work. People are therefore less inclined to act in income producing ways and will substitute leisure for work. But this tax also has an obvious income effect that influences the value of additional work at the margin as well as consumption choices in the product markets.

Taxing corporate income reduces the return on corporate capital thereby creating an incentive for capital to flow to the non-corporate sector. Optimal capital allocation would require equal after-tax returns on capital in all sectors lest investors be tempted to shift capital from one sector in response to higher returns elsewhere. That being so, a tax on corporate income would lead to some corporate investment opportunities being ditched in favor of investment opportunities in other sectors that may have lower pretax but higher after-tax returns than the corporate sector.

Excise taxes and general sales or use taxes introduce price distortions in the product markets that will create at least some measure of deadweight loss to society in all cases where the demand or supply exhibit some degree of elasticity. Buyers facing a new price regime that incorporates their incidence of taxation will respond by demanding less quantities of taxed goods. Producers absorb into their cost structure a portion of the tax that is consistent with their incidence of taxation. They end up willing to produce less quantities at any given market price. The market clears at lower quantities creating the vacuum of unfulfilled producer and consumer surplus known as dead-weight loss.

Taxing real property is a bit different in that land is fixed. A land tax primarily reduces the after tax return to the landholder and does not necessarily reduce output. It would, however, impact the economic value of the land creating a market distortion of its own sort.

Taxes are not going to go away and neither will the inefficiencies that come with them. But we can ask the question, "Given the experience of the 50 states, can we detect a discernable difference in either the economic level 
or rate of growth in output of the various states that bears some relationship to the portfolio of taxes on which the states have relied?".

\section{Related Literature}

The impact of taxes at the state level has received much attention from economists over the years. For a thorough summary of the relevant literature, interested readers are advised to consult the book, State Sales and Income Taxes-An Economic Analysis (Texas A\&M Press, 1999) by George R. Zodrow. Chapter 3 provides a very comprehensive (if not exhaustive) survey of relevant empirical work. In this chapter, Zodrow references and summarizes conclusions from a host of empirical studies that address the following issues:

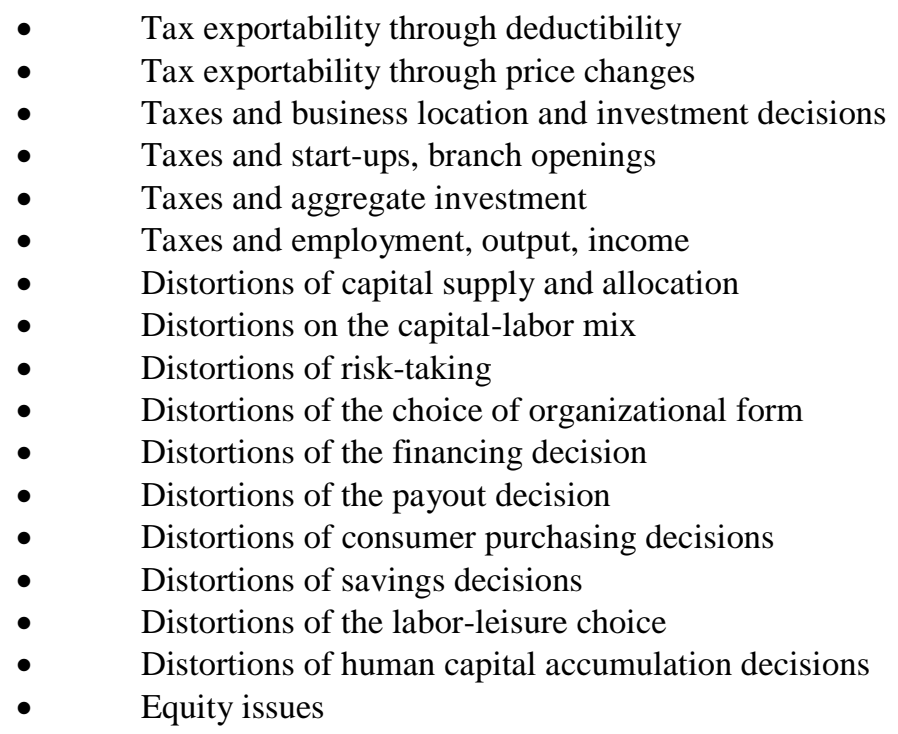

Zodrow also provides an extensive bibliography with over 200 entries noting important books and articles on the subject. More recent studies have been included in the references at the end of this article.

The results of previous studies are mixed. The fact that people keep coming back to examine various aspects of state and local taxation attests to the inconclusive state of the empirical research to date. Economic theory generally says that taxes matter. Previous research would not categorically refute that statement but it does not always support it. The results to date are sufficient to motivate researchers to keep looking for further evidence to increase our understanding of the impact of taxes.

\section{Methodology}

If the mix of taxes matters, then it is reasonable to expect to find some statistically significant relationship between the economic output of the states and the structure of the states' tax regimes. Tax regimes in this study are defined by the relative shares of an individual state's total taxes represented by property tax, general sales tax (including use tax), specific sales tax, individual income tax, corporate income tax and other tax. The absolute dollar amounts of taxes in each category are reported by the Bureau of the Census and are summarized for all of the states. A tax index was constructed for each tax on a state-by-state basis. The numerator of the index was a given state's particular tax share of that state's total tax revenue. The denominator was the average tax share for all 50 states for that specific type of tax. For example, in 1998 Nevada drew $62.3 \%$ of its total tax revenue from property taxes. Oregon by contrast only saw $10.3 \%$ of its total taxes that year coming from property. The average for all 50 states in 1998 was $36.2 \%$ of total tax revenue being derived from property. Thus the index for Nevada would be $1.721(62.3 / 36.2)$ and $.285(10.3 / 36.2)$ for Oregon. In similar fashion, an index was constructed for each tax, for 
each state, for the years 1993 through 1999. Table 1 presents each state's average tax shares over this period of time as well as the 50 states average for each type of tax.

TABLE 1: 1993-1999 Average Tax Shares

\begin{tabular}{|c|c|c|c|c|c|c|c|}
\hline $\begin{array}{l}1993-1999 \\
\text { Average State \& } \\
\text { Local Tax Shares }\end{array}$ & Property tax & $\begin{array}{c}\text { Sales and } \\
\text { gross receipts } \\
\text { tax }\end{array}$ & $\begin{array}{c}\text { General sales } \\
\text { tax }\end{array}$ & $\begin{array}{l}\text { Selective } \\
\text { sales tax }\end{array}$ & $\begin{array}{l}\text { Individual } \\
\text { income tax }\end{array}$ & $\begin{array}{l}\text { Corporate } \\
\text { income tax }\end{array}$ & \begin{tabular}{|c|c} 
Motor vehicle \\
license \& \\
other taxes
\end{tabular} \\
\hline Alabama & 0.127584 & 0.510736 & 0.311042 & 0.199694 & 0.219106 & 0.029514 & 0.113059 \\
\hline Alaska & 0.307703 & 0.108767 & 0.047936 & 0.060831 & 0.000000 & 0.159697 & 0.423833 \\
\hline Arizona & 0.299950 & 0.448599 & 0.346745 & 0.101855 & 0.160548 & 0.042942 & 0.047962 \\
\hline Arkansas & 0.167900 & 0.486563 & 0.348974 & 0.137589 & 0.240150 & 0.043120 & 0.062267 \\
\hline California & 0.263295 & 0.354975 & 0.267933 & 0.087042 & 0.251399 & 0.062223 & 0.068108 \\
\hline Colorado & 0.305922 & 0.368976 & 0.278840 & 0.090136 & 0.249593 & 0.021676 & 0.053833 \\
\hline Connecticut & 0.367580 & 0.311581 & 0.200806 & 0.110775 & 0.216042 & 0.049520 & 0.055278 \\
\hline Delaware & 0.146969 & 0.118606 & 0.000000 & 0.118606 & 0.325457 & 0.085523 & 0.323446 \\
\hline Florida & 0.353266 & 0.518139 & 0.348596 & 0.169543 & 0.000000 & 0.031039 & 0.097556 \\
\hline Georgia & 0.275255 & 0.391273 & 0.305780 & 0.085493 & 0.252944 & 0.038061 & 0.042467 \\
\hline Hawaii & 0.161411 & 0.514836 & 0.369828 & 0.145008 & 0.262783 & 0.015750 & 0.045219 \\
\hline Idaho & 0.262689 & 0.342864 & 0.236009 & 0.106855 & 0.261850 & 0.044844 & 0.087754 \\
\hline Illinois & 0.381009 & 0.334730 & 0.189485 & 0.145244 & 0.181414 & 0.048997 & 0.053850 \\
\hline Indiana & 0.334355 & 0.290936 & 0.211593 & 0.079343 & 0.281700 & 0.064358 & 0.028651 \\
\hline Iowa & 0.337688 & 0.318158 & 0.219628 & 0.098531 & 0.237282 & 0.028854 & 0.078018 \\
\hline Kansas & 0.308652 & 0.370507 & 0.271909 & 0.098598 & 0.215400 & 0.040901 & 0.064540 \\
\hline Kentucky & 0.167308 & 0.374540 & 0.211531 & 0.163009 & 0.310069 & 0.035691 & 0.112392 \\
\hline Louisiana & 0.159953 & 0.542400 & 0.399575 & 0.142825 & 0.140364 & 0.034279 & 0.123004 \\
\hline Maine & 0.405380 & 0.294865 & 0.207955 & 0.086910 & 0.221322 & 0.027248 & 0.051185 \\
\hline Maryland & 0.266766 & 0.261902 & 0.138296 & 0.123606 & 0.378751 & 0.023632 & 0.068949 \\
\hline Massachusetts & 0.336584 & 0.210219 & 0.118619 & 0.072103 & 0.348020 & 0.061652 & 0.043524 \\
\hline Michigan & 0.325109 & 0.300010 & 0.230160 & 0.069850 & 0.236460 & 0.085583 & 0.052839 \\
\hline Minnesota & 0.288625 & 0.310836 & 0.199701 & 0.111135 & 0.285624 & 0.045437 & 0.069478 \\
\hline Mississippi & 0.235798 & 0.509449 & 0.357708 & 0.151742 & 0.147908 & 0.040712 & 0.066132 \\
\hline Missouri & 0.233552 & 0.411078 & 0.291898 & 0.119180 & 0.256612 & 0.027805 & 0.070953 \\
\hline Montana & 0.431235 & 0.142258 & 0.000000 & 0.142258 & 0.217767 & 0.043577 & 0.165163 \\
\hline Nebraska & 0.361256 & 0.337529 & 0.231634 & 0.105895 & 0.205120 & 0.030461 & 0.065634 \\
\hline Nevada & 0.219717 & 0.638713 & 0.368988 & 0.269724 & 0.000000 & 0.000000 & 0.141571 \\
\hline New Hampshire & 0.647501 & 0.190529 & 0.000000 & 0.190529 & 0.017665 & 0.068546 & 0.075759 \\
\hline New Jersey & 0.463319 & 0.266660 & 0.156434 & 0.110226 & 0.181636 & 0.041556 & 0.046828 \\
\hline New Mexico & 0.123853 & 0.528810 & 0.406040 & 0.122770 & 0.169173 & 0.037781 & 0.140383 \\
\hline New York & 0.318566 & 0.265594 & 0.181086 & 0.084508 & 0.295534 & 0.074594 & 0.045712 \\
\hline North Carolina & 0.214919 & 0.365430 & 0.230003 & 0.135427 & 0.303203 & 0.052517 & 0.063931 \\
\hline North Dakota & 0.291749 & 0.408782 & 0.219897 & 0.188885 & 0.105407 & 0.050783 & 0.143279 \\
\hline Ohio & 0.287766 & 0.312901 & 0.211597 & 0.101304 & 0.309523 & 0.026515 & 0.063295 \\
\hline Oklahoma & 0.159180 & 0.413474 & 0.297169 & 0.116306 & 0.236445 & 0.026828 & 0.164073 \\
\hline
\end{tabular}




\begin{tabular}{|l|l|l|l|l|l|l|l|}
\hline Oregon & 0.333653 & 0.098106 & 0.000002 & 0.098104 & 0.395629 & 0.039035 & 0.133577 \\
\hline Pennsylvania & 0.281805 & 0.297275 & 0.189111 & 0.108164 & 0.242378 & 0.050779 & 0.127763 \\
\hline Rhode Island & 0.414878 & 0.294908 & 0.170981 & 0.123927 & 0.218795 & 0.028313 & 0.043106 \\
\hline South Carolina & 0.279338 & 0.365502 & 0.263915 & 0.101587 & 0.243053 & 0.030772 & 0.081336 \\
\hline South Dakota & 0.384357 & 0.484900 & 0.349249 & 0.135650 & 0.000054 & 0.026668 & 0.104021 \\
\hline Tennessee & 0.224610 & 0.613126 & 0.457177 & 0.155949 & 0.012001 & 0.048824 & 0.101439 \\
\hline Texas & 0.377048 & 0.502358 & 0.322793 & 0.179564 & 0.000008 & 0.000000 & 0.120587 \\
\hline Utah & 0.239637 & 0.418438 & 0.323792 & 0.094647 & 0.260078 & 0.035356 & 0.046491 \\
\hline Vermont & 0.436459 & 0.264684 & 0.117687 & 0.146997 & 0.199344 & 0.027688 & 0.071825 \\
\hline Virginia & 0.307670 & 0.302633 & 0.162509 & 0.140124 & 0.283417 & 0.023879 & 0.082401 \\
\hline Washington & 0.307890 & 0.600525 & 0.468629 & 0.131896 & 0.000000 & 0.000000 & 0.091585 \\
\hline West Virginia & 0.193856 & 0.415227 & 0.217798 & 0.197429 & 0.205438 & 0.059979 & 0.125501 \\
\hline Wisconsin & 0.346690 & 0.282008 & 0.190126 & 0.091881 & 0.281300 & 0.040765 & 0.049238 \\
\hline Wyoming & 0.382085 & 0.338972 & 0.277671 & 0.061301 & 0.000000 & 0.000000 & 0.278943 \\
\hline Average & 0.296987 & 0.363098 & 0.238497 & 0.124211 & 0.201275 & 0.041085 & 0.097555 \\
\hline
\end{tabular}

Economic output was calculated on a per capita basis using Gross State Product (as reported by the Bureau of Economic Analysis) divided by Census Bureau state population data. The 50 states average per capita GSP was calculated and then used to develop an index of relative economic output. In 1999, California had a real per capita gross state product of $\$ 35,771$ while the average for all states that year was $\$ 31,356$. This yields an index of per capita GSP of 1.141 for California in 1999.

Economic growth was measured by dividing the real per capita gross state product in one year by the real per capita gross state product from the previous year. Calculated in this manner, a 5\% growth for a given state would result in a number of 1.05. These results were then used to produce a ratio of average growth for all 50 states. A relative growth index was calculated using the state specific growth ratios in the numerator and the state average growth ratio in the denominator. In 1999, California had growth ratio of 1.0661 reflecting $6.61 \%$ growth in real per capita gross state product. The average growth ratio for all 50 states that year was 1.034. Thus, California's 1999 relative growth index would be 1.031 (1.0661/1.034).

Ordinary least squares was used to test the relationship between economic well-being and tax structure. The dependent variables were indexes of levels and growth in per capita GSP as discussed above. The independent variables were indexes of relative tax shares, also previously discussed. Data for the years 1993 through 1999 were used and tested both on a year-by-year cross-sectional basis and also on a cross-sectional pooled basis for the cumulative 1993 to 1999 year period. The categories of taxes examined were property taxes, consumption taxes, income taxes and other taxes. The consumption taxes were most broadly categorized as gross receipts taxes and then more narrowly as general sales and selective sales taxes. Income taxes were categorized on the individual and corporate levels. The remaining taxes were grouped and categorized as other taxes.

The general format of the regression equations would be:

Index of relative annual per capita growth in real GSP $=\alpha+\beta$ (tax share index)

Index of relative per capita real GSP $=\alpha+\beta$ (tax share index)

The results are reported in Tables 2 and 3.

Summary and discussion of results 
In general, the results for the cross-sectional pooled data were more statistically robust than the year-byyear cross sectional data alone. This is attributable to the fact that there would be collectively 350 data points for the seven year period rather than just the 50 individual state data points for a given year. The resulting R-squares are generally low but this would be logical given the complex nature economic output and growth and all the factors that could go into explaining it. Tax structure, if it had an impact at all, would not be expected to play a dominant explanatory role in understanding the relative per capita levels or growth rates of gross state product for the 50 individual states.

\section{Property Taxes}

If a state has a greater than average share of its total tax revenues attributable to property taxes, then that state is likely to experience above average levels and growth of per capita real gross state product. R-squares for the 1993-99 period are .026 for levels of GSP and .054 for growth in GSP for that same period. The respective estimated coefficients for the property tax index are positive and significant at greater than a $99.9 \%$ confidence level. The degree of explanatory power, while statistically significant, is not impressive with respect to the relative levels of per capita GSP. Only $2.6 \%$ of the variation in the index of relative per capita level of GSP can be explained by the property tax index. The results from testing the 7 years individually yield results that are similar in terms of magnitude and sign but lack the same degree of statistical robustness.

The index of relative property tax shares does a bit better explaining $5.4 \%$ of the variation in the index of relative growth in per capita GSP. The data tested on a year-by-year basis produced similar results with statistical significance at a greater than $90 \%$ confidence level for the estimated tax variable coefficient in 4 of the 7 years.

A plausible economic argument can be made for these results. To the extent that the supply of taxable property is relatively fixed in the short-run, then taxing property should not create any dead-weight loss to the economy. In exhibit $1, \mathrm{D}_{0}$ and $\mathrm{D}_{\mathrm{T}}$ represent the effective demand for property on a before and after tax basis respectively with the vertical distance between the demand curves reflecting the absolute value of the tax.

\section{EXHIBIT 1}

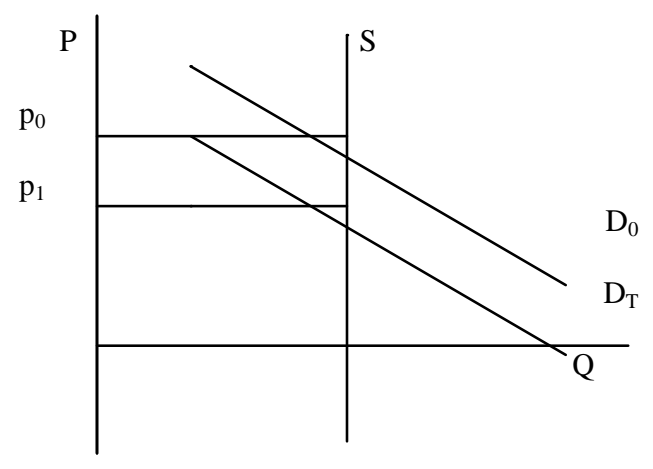

Because supply is fixed, the incidence of tax falls completely on the supplier of property with no change in either the market clearing price or quantity. Should there be any elasticity in the supply curve at all, it would have an impact on both the market clearing price, the after tax price to the supplier and quantity supplied thereby creating some deadweight loss to society. Price distortions aside, property taxes could be considered advantageous over sales taxes on items that have a normal supply curve due to the deadweight losses associated with the latter.

To the extent that a tax at the state level is deductible against federal taxable income, states have the ability to export some of the economic burden of a given state tax to the federal level. For example, if a taxpayer is in a $30 \%$ federal tax bracket and pays a $\$ 2000$ state tax on property, the after tax effect of the property tax is $\$ 1400$. The 
$\$ 2000$ property tax was offset by the $\$ 600$ value of the property tax deduction on the federal tax return. Because property taxes are in this sense "exportable", it would be consistent to find that states that place greater than average reliance on property taxes would have a higher economic well-being.

\section{Gross Receipts Taxes}

If a state has a greater than average share of its total tax revenues attributable to gross receipts taxes, then that state is likely to experience below average levels of per capita gross state product. The evidence for a relationship between relative tax share and per capita growth in real GSP in not as compelling. For the 1993-99 time period, the r-square for estimating the relationship between the index of per capita level of GSP and gross receipts tax index was .118. The tax index coefficient was negative and had a t-statistic of -6.82 indicating statistical significance at a greater than $99.9 \%$ confidence level. The 1993-99 relationship between per capita growth index and gross receipts tax index also resulted in negative tax index coefficient with a t-statistic of -2.38 indicating significance at a 98\% confidence level. The associated r-square however, was only .017 indicating very little explanatory power. Examination of the data on a year-by-year cross sectional basis reinforced the conclusion of a significant relationship between an index of per capita level of GSP and a gross receipts tax index. The resultant $r-$ squares ranged from .10 to .12 and the coefficients were significant at a $98 \%$ confidence level or higher for all 7 years. In terms of explaining growth of per capita GSP, only 1 of the 7 periods (1995) resulted in a statistically significant coefficient for the gross receipts tax index, and that only at a $90 \%$ confidence level. To the extent that there is some degree of causality between economic well-being and tax structure, it is being picked up in the level of per capita output but not in this formulation of growth.

Elementary analysis of tax that is routinely presented in introductory economics texts provides at least some theoretical justification for this result. In exhibit 2 below, a constant dollar excise tax is represented by the vertical distance between the before $\left(S_{0}\right)$ and after tax $\left(S_{T}\right)$ supply curves. The introduction of the tax results in a lower quantity of output. Given the demand function, the incidence of tax is shared by consumers and producers. The deadweight loss in economic efficiency is the triangular area representing reduced consumer and producer surplus due to the introduction of the excise tax.

\section{EXHIBIT 2}

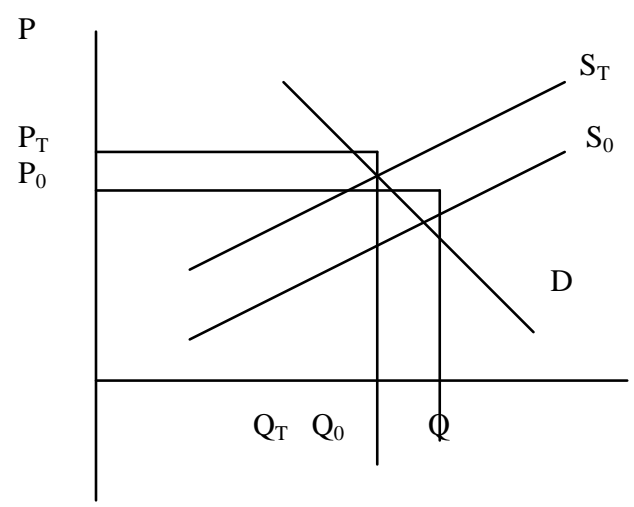

The textbook story is consistent with the empirical results showing a statistically significant relationship between above average reliance on sales taxes and below average levels of per capita GSP.

Unlike property taxes, sales taxes are no longer deductible against federal taxable income for individuals. States are not in a position to export sales taxes to the federal level. They absorb the impact largely within their constituency. The empirical results of this study are consistent with this fact. 


\section{General Sales and Selective Sales Taxes}

Gross receipts taxes are composed of general sales and selective (excise) taxes. As such, the results for these subsets closely mirror the results of the more generalized categorization. States that have above shares of their total tax revenues coming from general or selective sales taxes are likely to be experiencing below average levels of per capita gross state product. R-squares for the equations explaining 1993-99 levels of per capita levels of GSP using general sales and selective sales tax indexes were .087 and .070 , respectively. The coefficients were negative and significant at confidence levels exceeding $99.9 \%$. The results were affirmed when tested on a year-by-year cross sectional basis.

With respect to the 1993-99 indexes of growth in per capita GSP, the resultant coefficient of the general sales tax index variable was negative and significant at a $96 \%$ confidence level but the explanatory power as measured by $r$-square was only .013. On a year-by-year basis, the same coefficient was statistically significant in only 1 of 7 years. The selective sales tax index coefficient had virtually no statistically significant power to explain the per capita growth index for either the pooled 1993-99 data or the individual years.

\section{Individual Income Tax}

A weak but statistically significant positive relationship between the index of annual growth in per capita gross state product and the index for individual income tax share was evidenced in the 1993-99 pooled data. The resultant $r$-square was only .022 but the coefficient for the tax variable was positive and significant at a $99 \%$ confidence level. It is hard to place too much confidence in this result because when testing on a year-by-year basis, statistical significance at a confidence level of $90 \%$ or greater for the tax index coefficient was achieved for only 1 of the 7 years. Furthermore, there was no statistically significant relationship between the index of per capita level of GSP and the individual income tax index. This was true using the pooled data or the individual years.

Taxing income theoretically reduces incentives to work thereby, influencing the work leisure tradeoff in the direction of more leisure and less work. But to the extent that people are committed to maintaining an existing standard of living and wealth, then they would have to work more in order to maintain the same after-tax standards. These two forces would offset each other. The empirical results suggest that at the state level, these forces virtually cancel each other out and taxing individual income is more neutral than taxing either property or gross receipts.

Individual income taxes are deductible against federal income and are therefore exportable to the federal level. Individual income taxes appear to be neutral in terms of relative levels and growth of per capita GSP. If the exportable nature of income taxes is having a positive effect on the economic well-being of the states, it would only be to the extent that it is helping to offset the disincentives to engage in income producing behavior attributable to taxing income.

\section{Corporate Income Tax}

States that have a greater than average share of tax revenues attributable to corporate income tax are likely to have higher than average levels of per capita GSP. In terms of r-square, the corporate income tax index explained $12 \%$ of the variation in the index of per capita level of GSP with a positive tax index coefficient significant at a greater than $99.99 \%$ confidence level. The results were supported in all 7 of the years tested individually. The results for the regressions testing the relationship between tax structure and growth did not demonstrate any statistical significance. This was somewhat surprising given the rather robust results of the regressions testing the index of per capita levels of GSP against the index of corporate income tax.

From a theoretical point of view, the primary disadvantage to taxing corporate income is that it encourages capital to move from the corporate sector (which would now be suffering from lower after tax returns) and flow into non corporate sectors which offer lower gross but higher after-tax net returns. The practical realities are such that returns to capital are taxed in all sectors. Corporate income tax rates at the state level are much lower than at the federal level. Therefore it is hard to imagine that state level corporate income taxes, as currently structured, would 
have any significant influence on capital flows. Even the fact that states approach taxing corporate income very differently should not be expected to have a great amount of influence on corporate behavior in terms of where a corporate business decides to locate itself. This is because corporations by statute generally must apportion their income and pay tax to the various states where they have an economic presence. The apportionment formulas are based upon sales, payroll and property in the various states with the sales factor being double weighted. So a corporation physically located primarily in a low or no income tax state might well still find itself paying hefty income tax bills to any other state where it has established an economic presence.

State income taxes paid by corporations are deductible against federal taxable income, therefore states have the ability to "export" these taxes to the federal level. But due to the nature of corporate income taxation at the state level, any given state is also able to take advantage of the income producing activities of out-of-state corporations that nevertheless have established an economic presence within that state. The presence may be as little as having one part-time employee in the state or storing limited amounts of inventory within a state or having a service representative enter the state once in a given year to service a product sold to a customer in that state. Any of these conditions would be sufficient to establish a taxable nexus within a state with respect to income tax. Once established, the out-of-state corporate income would be apportioned to that state using an apportionment formula based on double weighted sales, property and payroll for a given state divided by that corporation's total sales, property and payroll in all states. As such, sales into a given state by out-of-state corporations have a very significant impact on the state's corporate tax revenue. The empirical result here is most likely picking up the fact that states with relatively higher per capital levels of income make relatively more purchases in general. Out-ofstate corporations will in turn sell relatively more to customers in these wealthier states and thereby apportion more income and pay more tax to those same states.

\section{Other Taxes}

Taxes other than taxes on property, consumption and income fall into the "other taxes" category. The percentage of a state's total tax revenue falling into this category averages $7.4 \%$ for all 50 state but varies widely from state to state with a high of $40 \%$ for Alaska and a low of 1.8\% for Indiana. Examples of these taxes would be franchise taxes on business capital, permits and fees, airport or port authority taxes and such. It is an eclectic categorization and produced results consistent with its eclectic nature. To the extent that states have a greater than average share of tax revenues falling into this category, they are likely to be experiencing above average levels of per capita GSP but below average rates of growth. The equation for regressing the 1993-99 indexes of per capita levels of GSP against the other tax indexes resulted in an r-square of .158 and a positive coefficient for the tax index coefficient significant at a greater than $99.99 \%$ confidence level. The equation for regressing the 1993-99 indexes of annual growth in per capita GSP resulted in a lower r-square of .087 and a negative coefficient for the tax index that was significant at a greater than $99.99 \%$ level of confidence. Both results were supported when examining the individual years. The result is perplexing because on one hand, above average reliance on other taxes suggests above average levels of per capita GSP. On the other hand, it also suggest that these states will be experiencing lower rates of growth.

Theoretical analysis of this category of tax is difficult because of eclectic nature of the category. The difference in the signs of the estimated coefficient for the tax variable, positive for per capita levels of GSP but negative for growth in per capita GSP, is consistent with the mixed nature of the category. This is unfortunate because the category as a whole has a greater average tax share than corporate income taxes. The average share of total tax revenue for other taxes is $9.8 \%$ and only $4.2 \%$ for corporate income tax.

\section{Conclusions}

Does the relative mix of taxes that a state imposes have any discernable impact on that state's relative economic well being? Based upon the empirical results of this study, an appropriate response could be a resounding, "Maybe!". Table 4 below summarizes the relationships examined in this study: 
TABLE 4 Summary of Relationships Between Relative Tax Structure And Relative Economic Well-being

\begin{tabular}{|l|l|l|l|}
\hline & $\begin{array}{l}\text { Tax Share Relative } \\
\text { to 50 State Average }\end{array}$ & Level of Per Capita GSP & $\begin{array}{l}\text { Growth Rate of Per } \\
\text { Capita GSP }\end{array}$ \\
\hline \multicolumn{1}{|c|}{ Property Tax } & Above Average & Above Average & Above Average \\
\hline Gross Receipts Tax & Above Average & Below Average & Below Average \\
\hline General Sales Tax & Above Average & Below Average & Below Average \\
\hline Selective Sales Tax & Above Average & Below Average & Not Statistically Significant \\
\hline Individual Income Tax & Above Average & Not Statistically Significant & Not Statistically Significant \\
\hline Corporate Income Tax & Above Average & Above Average & Not Statistically Significant \\
\hline Other Taxes & Above Average & Above Average & Above Average \\
\hline
\end{tabular}

There are many limitations to this study and certainly a significant one would have to be the issue of causation. A state with a higher than average share of tax revenue coming from property taxes is likely to have a higher than average level and growth rate of per capita GSP. But is the tax mix responsible for the above average level and growth of the states' per capita GSP or is it the above average level and growth of GSP that is generating the above average share of taxes from property? Similar questions could be raised with respect to consumption, corporate income and other tax categories. This problem of causation makes it difficult to draw conclusions that are much stronger than "maybe".

Is there a statistically discernable relationship between the relative mix of taxes that a state adopts and the state's relative economic well being? The answers here are more definitive and summarized in the above table. It is interesting to note that the taxes that are more "exportable" to the federal level, i.e., property tax and corporate income tax, have a positive relationship between relative tax share and economic well-being. Consumption taxes are not as exportable to the federal level and have a negative relationship to a state's relative economic well-being.

\section{Suggestions For Future Research}

The formulation for economic well-being in this study is admittedly naïve. It assumes that the impact of the relative tax structure on level and growth of per capita GSP is immediate and concurrent within the same year. A greater understanding of the probable lags would be helpful. Discerning causation, as has been noted, is a problem. Statistical methods such as Granger causation tests might prove useful in enhancing our understanding of this issue. The data used in this study reflects the relatively recent economic experience of the United States during the decade of the 90's. This was in general a period of sustained economic expansion. It would be interesting to see whether these results would be replicated during periods of time that included economic downturns. The variations in tax structure for the 50 states provided the fodder for testing the relationships between tax structure and economic well-being. A similar methodology could be used with country data that would also reflect various mixes of taxation.

\section{References}

1. Aaron, H., Pechman, J., How Taxes Affect Economic Behavior, The Brookings Institution, Washington, D.C., 1981.

2. Ando, A., Blume, M., Friend, I., The Structure and Reform of the U.S. Tax System, MIT Press. Cambridge, MA., 1985.

3. Atkinson, A.B., Modern Public Finance, Vol's I and II, Edward Elgar Ltd., Brookfield, Vermont, 1991.

4. Bacon, K., "Differential Taxes, State Aids and the Lunn Poly Case", European Competition Law Review: ECLR, 20, no.7, 1999.

5. $\quad$ Browning, E., Browning, J., Public Finance and the Price System, $3^{\text {rd }}$ ed., Macmillan, New York, 1987.

6. Buckley, F.H., Rasmusen, E., "The Uneasy Case for the Flat Tax", Constitutional Political Economy, Vo. 11, no. 4 , pp. 295-318, 2000. 
7. Buss, T., "The Effect of State Tax Incentives on Economic Growth and Firm Location Decisions: An Overview of the Literature", Economic Development Quarterly, Vol 15, no. 1 pp. 90-105, 2000.

8. CCH State Tax Advisory Board, A Roundtable Discussion by the CCH State Tax Advisory Board, Taxes, Vol. 80, no. 2 pp. 13-29, 2002.

9. Chernick, H., "A Model of the Distributional Tax Incidence of State and Local Taxes", Public Finance Quarterly, Vol. 20, no. 4, pp. 572-585, Oct. 1992.

10. Dahlby, B., "Taxing Choices: Issues in the Assignment of Taxes in Federations", International Social Science Journal, Vol. 53, no. 167 pp. 93-101, 2001.

11. Durbin, E., "Recent Trends in State Corporate Income Taxes", Spectrum, Vol. 74, no. 1, pp. 5-7, Winter 2001.

12. Fisher, P., Peters, A., "Industrial Incentives: Competition Among American States and Cities", Journal of Planning Literature, Vol. 14, no. 1, 1999.

13. Gittel, R., Kaufman, A., "The New Economic Geography of the States", Economic Development Quarterly, Vol. 14, no. 2, pp. 182-193 2000.

14. Gius, M., Frese, P., "The Impact of State Personal and Corporate Tax Rates on Firm Location", Applied Economic Letters, Vol.9, no. 1, pp. 47-49, 2002.

15. Hyman, D., Public Finance-A Contemporary Application of Theory to Policy, $6^{\text {th }}$ ed. Dryden Press, Harcourt Brace Publisher, 1999.

16. Hendricks, L., "How Do Taxes Affect Human Capital? The Role of Intergenerational Mobility", Review of Economic Dynamics, Vol. 4, no. 3, pp. 695-735, 2001.

17. Hoyt, W., "Tax Policy Coordination, Vertical Externalities, and Optimal Taxation in a System of Hierarchical Governments", Journal of Urban Economics, Vol. 50, no. 3, pp. 491-516, 2001.

18. Jelavich, M., "Manufacturing and Rural Economies in the United States; The Role of Nondurable Producers, Labor Costs and State Taxes", American Journal of Economics and Sociology, Vol. 60, no. 1, pp. 185-192, January 2001.

19. Kiser, E., Linton, A., "Determinants of the Growth of the State: War and Taxation in Early Mondern France and England", Social Forces, Vol. 80, no. 2, pp. 411-448, 2001.

20. Long, J., "The Impact of Marginal Tax Rates on Taxable Income: Evidence from State Income Tax Differentials", Southern Economic Journal, Vol. 65, no. 4, pp. 855-869, April 1999.

21. Mikesell, J., "State Tax Policy: A Political Perspective”, Choice, Vol. 39, no. 6, pp. 1090, Feb 2002.

22. Mullins, D., Wallace, S., "Changing Demographics and State Fiscal Outlook: The Case of Sales Taxes", Public Finance Quarterly, Vol. 24, no. 2, pp. 237-263, 1996.

23. Oates, W., "Local Government Tax and Land-Use Policies in the United States: Understanding the Links", Journal of Planning Literature, Vol. 13, no. 3, 1999.

24. Petchey, J., Shapiro, P., "The Efficiency of State Taxes on Mobile Labour Income", The Economic Record, Vol. 76, no. 234, pp. 285-297, 2000.

25. Seung, C., Kraybill, D., "Tax Incentives in an Economy with Public Goods ", Growth \& Change, Vol. 30, no. 1, pp. 128-147, Winter 1999.

26. Sheffrin, S., "State Sales and Income Taxes", National Tax Journal, Vol. 53, no. 4, pp. 965-969, Dec 2000.

27. Smith, A., The Wealth of Nations, 1776.

28. Stiglitz, J., Economics of the Public Sector, $1^{\text {st }}$ ed., W.W. Norton \& Co., New York, 1986.

29. Ulbrich, H., "The Future of State Taxation”, Choice, Vol. 36, no. 6 pp. 1104, Feb 1999.

30. Wei, Y., Wallace, M., Nardinelli, C., "State Growth Rates: Taxes, Spending, and Catching Up”, Public Finance Quarterly, Vol. 19, no. 1, pp. 80+, Jan 1991.

31. Zodrow, G. R., State Sales and Income Taxes: An Economic Analysis, Texas A\&M, 1999. 
TABLE 2: Regression Results for Relationship Between Index of Relative Level of Per Capita GSP and Tax Share Index

\begin{tabular}{|c|c|c|c|c|c|c|c|}
\hline $\begin{array}{l}\text { Index of Relative Level of Per } \\
\text { Capita Real GSP Related to Tax } \\
\text { Share Index }\end{array}$ & \begin{tabular}{|l} 
Property \\
Tax Index
\end{tabular} & $\begin{array}{c}\text { Gross } \\
\text { Receipts } \\
\text { Tax Index } \\
\end{array}$ & $\begin{array}{c}\text { General } \\
\text { Sales Tax } \\
\text { Index } \\
\end{array}$ & $\begin{array}{c}\text { Selective } \\
\text { Sales Tax } \\
\text { Index } \\
\end{array}$ & \begin{tabular}{|c|} 
Individual \\
Income Tax \\
Index \\
\end{tabular} & \begin{tabular}{|c|} 
Corporate \\
Income Tax \\
Index \\
\end{tabular} & \begin{tabular}{|c|c|}
$\begin{array}{c}\text { Other Tax } \\
\text { Index }\end{array}$ \\
\end{tabular} \\
\hline \multicolumn{8}{|l|}{ 1993-99 Pooled Data } \\
\hline R Square & 0.025902 & 0.117959 & 0.08732 & 0.069629 & 0.004978 & 0.120815 & 0.158563 \\
\hline F Stat & 9.253728 & 46.53931 & 33.29473 & 26.046 & 1.74117 & 47.8211 & 65.5783 \\
\hline Significance of F Stat & 0.002529 & 0.000001 & 0.000001 & 0.000001 & 0.187857 & 0.000001 & 0.000001 \\
\hline Constant & 0.918599 & 1.165997 & 1.105765 & 1.133886 & 1.02222 & 0.911573 & 0.929407 \\
\hline t Stat for Constant & 32.5606 & 45.236 & 54.56256 & 41.0081 & 53.4894 & 59.3895 & 77.18925 \\
\hline P-value for Constant & 0.000001 & 0.000001 & 0.000001 & 0.000001 & 0.000001 & 0.000001 & 0.000001 \\
\hline Coefficient for Tax Index Variable & 0.081361 & -0.166 & -0.10577 & -0.13389 & -0.02222 & 0.088427 & 0.070592 \\
\hline t Stat for Tax Index Variable & 3.041994 & -6.82197 & -5.77016 & -5.10339 & -1.31953 & 6.915284 & 8.09805 \\
\hline P-value for Tax Index Variable & 0.002529 & 0.000001 & 0.000001 & 0.000001 & 0.187857 & 0.000001 & 0.000001 \\
\hline \multicolumn{8}{|l|}{1999} \\
\hline R Square & 0.064175 & 0.119491 & 0.079949 & 0.084518 & 0.00009 & 0.069905 & 0.07511 \\
\hline F Stat & 3.291621 & 6.51394 & 4.170998 & 4.431401 & 0.004485 & 3.607649 & 3.898091 \\
\hline Significance of F Stat & 0.075887 & 0.013941 & 0.046636 & 0.040543 & 0.946884 & 0.063533 & 0.05411 \\
\hline Constant & 0.872575 & 1.166899 & 1.101513 & 1.147451 & 1.002998 & 0.926386 & 0.942424 \\
\hline t Stat for Constant & 11.802 & 16.88112 & 20.12731 & 15.57422 & 19.76946 & 20.54924 & 25.39091 \\
\hline P-value for Constant & 0.000001 & 0.000001 & 0.000001 & 0.000001 & 0.000001 & 0.000001 & 0.000001 \\
\hline Coefficient for Tax Index Variable & 0.126985 & -0.1669 & -0.10513 & -0.14745 & -0.003 & 0.073614 & 0.057576 \\
\hline t Stat for Tax Index Variable & 1.814283 & -2.55224 & -2.0423 & -2.10509 & -0.06697 & 1.899381 & 1.974358 \\
\hline P-value for Tax Index Variable & 0.075887 & 0.013941 & 0.046636 & 0.040543 & 0.946884 & 0.063533 & 0.05411 \\
\hline \multicolumn{8}{|l|}{1998} \\
\hline R Square & 0.064242 & 0.12758 & 0.113468 & 0.067762 & 0.00156 & 0.086384 & 0.096578 \\
\hline F Stat & 3.295339 & 7.019392 & 6.143558 & 3.488999 & 0.075006 & 4.538475 & 5.131314 \\
\hline Significance of F Stat & 0.075727 & 0.010884 & 0.016756 & 0.067889 & 0.785358 & 0.038293 & 0.028049 \\
\hline Constant & 0.875912 & 1.167649 & 1.112442 & 1.134049 & 1.012066 & 0.919516 & 0.942588 \\
\hline t Stat for Constant & 12.15478 & 17.42694 & 22.02499 & 15.06214 & 20.25612 & 20.90105 & 27.85748 \\
\hline P-value for Constant & 0.000001 & 0.000001 & 0.000001 & 0.000001 & 0.000001 & 0.000001 & 0.000001 \\
\hline Coefficient for Tax Index Variable & 0.124088 & -0.16765 & -0.11244 & -0.13405 & -0.01207 & 0.080484 & 0.057412 \\
\hline t Stat for Tax Index Variable & 1.815307 & -2.64941 & -2.47862 & -1.86789 & -0.27387 & 2.13037 & 2.26524 \\
\hline P-value for Tax Index Variable & 0.075727 & 0.010884 & 0.016756 & 0.067889 & 0.785358 & 0.038293 & 0.028049 \\
\hline \multicolumn{8}{|l|}{1997} \\
\hline R Square & 0.028682 & 0.117029 & 0.08586 & 0.070745 & 0.002212 & 0.083198 & 0.137722 \\
\hline F Stat & 1.41737 & 6.361918 & 4.508384 & 3.654252 & 0.106392 & 4.355927 & 7.666511 \\
\hline Significance of F Stat & 0.239691 & 0.01503 & 0.038911 & 0.000001 & 0.745708 & 0.042214 & 0.007972 \\
\hline Constant & 0.917418 & 1.161214 & 1.102839 & 1.138531 & 1.014497 & 0.91563 & .9 .84049 \\
\hline t Stat for Constant & 12.5272 & 17.14599 & 20.60397 & 14.97629 & 20.12175 & 19.72491 & 29.90651 \\
\hline P-value for Constant & 0.000001 & 0.000001 & 0.000001 & 0.000001 & 0.000001 & 0.000001 & 0.000001 \\
\hline Coefficient for Tax Index Variable & 0.082582 & -0.16121 & -0.10284 & -0.13853 & -0.0145 & 0.08437 & 0.061595 \\
\hline t Stat for Tax Index Variable & 1.190533 & -2.52228 & -2.1233 & -1.91161 & -0.32618 & 2.087086 & 2.768846 \\
\hline P-value for Tax Index Variable & 0.239692 & 0.01503 & 0.038911 & 0.061906 & 0.745708 & 0.042214 & 0.007972 \\
\hline
\end{tabular}


TABLE 3: Regression Results for Relationship Between Index of Relative Growth in GSP and Tax Share Index

\begin{tabular}{|c|c|c|c|c|c|c|c|}
\hline $\begin{array}{l}\text { Index of Relative Growth in Per } \\
\text { Capita Real GSP Growth As Related } \\
\text { to Tax Share Index }\end{array}$ & $\begin{array}{c}\text { Property } \\
\text { Tax Index }\end{array}$ & \begin{tabular}{|c|} 
Gross \\
Receipts \\
Tax Index \\
\end{tabular} & $\begin{array}{c}\text { General } \\
\text { Sales Tax } \\
\text { Index }\end{array}$ & $\begin{array}{c}\text { Selective } \\
\text { Sales Tax } \\
\text { Index }\end{array}$ & \begin{tabular}{|c|} 
Individual \\
Income Tax \\
Index \\
\end{tabular} & $\begin{array}{c}\text { Corporate } \\
\text { Income Tax } \\
\text { Index }\end{array}$ & $\begin{array}{c}\begin{array}{c}\text { Other Tax } \\
\text { Index }\end{array} \\
\end{array}$ \\
\hline \multicolumn{8}{|l|}{ 1993-99 Pooled Data } \\
\hline R Square & 0.053702 & 0.016077 & 0.0132 & 0.007702 & 0.0216 & 0.006255 & 0.087113 \\
\hline F Stat & 19.74874 & 5.68637 & 4.6549 & 2.70123 & 7.6828 & 2.19033 & 33.20836 \\
\hline Significance of F Stat & 0.000001 & 0.017632 & 0.031648 & 0.101174 & 0.005874 & 0.139783 & 0.000001 \\
\hline Constant & 0.987591 & 1.006488 & 1.04354 & 1.004714 & 0.995099 & 1.00213 & 1.00554 \\
\hline t Stat for Constant & 335.4717 & 349.2081 & 450.1294 & 32.3381 & 495.9879 & 580.05 & 757.3153 \\
\hline P-value for Constant & 0.000001 & 0.000001 & 0.000001 & 0.000001 & 0.000001 & 0.000001 & 0.000001 \\
\hline Coefficient for Tax Index Variable & 0.012403 & -0.00649 & -0.00435 & -0.00471 & 0.004901 & -0.00213 & -0.00554 \\
\hline t Stat for Tax Index Variable & 4.443955 & -2.38461 & -2.15752 & -1.64354 & 2.771794 & -1.47998 & -5.76267 \\
\hline P-value for Tax Index Variable & 0.00001 & 0.017632 & 0.031649 & 0.101174 & 0.005875 & 0.139784 & 0.000001 \\
\hline \multicolumn{8}{|l|}{1999} \\
\hline R Square & 0.063587 & 0.022856 & 0.001669 & 0.129821 & 0.025449 & 0.0095 & 0.178094 \\
\hline F Stat & 3.259436 & 1.122735 & 0.080265 & 7.161039 & 1.25347 & 0.460359 & 10.40087 \\
\hline Significance of F Stat & 0.077287 & 0.294633 & 0.778157 & 0.010162 & 0.268462 & 0.500715 & 0.002269 \\
\hline Constant & 0.987884 & 1.006972 & 1.001401 & 1.07456 & 0.995273 & 1.002592 & 1.008468 \\
\hline t Stat for Constant & 139.8379 & 144.769 & 183.8975 & 148.2896 & 208.0258 & 225.6146 & 301.7384 \\
\hline P-value for Constant & 0.000001 & 0.000001 & 0.000001 & 0.000001 & 0.000001 & 0.000001 & 0.000001 \\
\hline Coefficient for Tax Index Variable & 0.012074 & -0.00697 & -0.0014 & -0.01746 & 0.004726 & -0.00259 & -0.00847 \\
\hline t Stat for Tax Index Variable & 1.805391 & -1.05959 & -0.28331 & -2.67601 & 1.119585 & -0.6785 & -3.22504 \\
\hline P-value for Tax Index Variable & 0.077287 & 0.294633 & 0.778157 & 0.010162 & 0.268462 & 0.500715 & 0.002269 \\
\hline \multicolumn{8}{|l|}{1998} \\
\hline R Square & 0.086008 & 0.00389 & 0.007401 & 0.000521 & 0.00385 & 0.013118 & 0.13245 \\
\hline F Stat & 4.51687 & 0.187469 & 0.357918 & 0.025044 & 0.185506 & 0.638036 & 7.328239 \\
\hline Significance of F Stat & 0.038736 & 0.666971 & 0.552477 & 0.87492 & 0.668611 & 0.428358 & 0.009374 \\
\hline Constant & 0.987411 & 1.003242 & 1.00318 & 1.001302 & 0.997902 & 1.003473 & 1.007444 \\
\hline t Stat for Constant & 124.8077 & 126.5689 & 169.5434 & 116.0112 & 180.6081 & 198.2288 & 274.4369 \\
\hline P-value for Constant & 0.000001 & 0.000001 & 0.000001 & 0.000001 & 0.000001 & 0.000001 & 0.000001 \\
\hline Coefficient for Tax Index Variable & 0.015896 & -0.00324 & -0.00318 & -0.0013 & 0.002098 & -0.00347 & -0.00744 \\
\hline t Stat for Tax Index Variable & 2.125293 & -0.43298 & -0.59826 & -0.15825 & 0.430704 & -0.79877 & -2.70707 \\
\hline P-value for Tax Index Variable & 0.038736 & 0.666971 & 0.552477 & 0.87492 & 0.668611 & 0.428358 & 0.009374 \\
\hline \multicolumn{8}{|l|}{1997} \\
\hline R Square & 0.030224 & 0.014841 & 0.006123 & 0.029314 & 0.065457 & 0.013448 & 0.125252 \\
\hline F Stat & 1.495959 & 0.723109 & 0.295725 & 1.449579 & 3.361983 & 0.654288 & 6.872973 \\
\hline Significance of F Stat & 0.227265 & 0.399348 & 0.589092 & 0.234499 & 0.072922 & 0.422575 & 0.011688 \\
\hline Constant & 0.991264 & 1.005916 & 1.00283 & 1.009189 & 0.991873 & 1.003495 & 1.006053 \\
\hline t Stat for Constant & 131.4593 & 136.4589 & 174.3716 & 126.0463 & 197.2697 & 202.2356 & 308.9217 \\
\hline P-value for Constant & 0.000001 & 0.000001 & 0.000001 & 0.000001 & 0.000001 & 0.000001 & 0.000001 \\
\hline Coefficient for Tax Index Variable & 0.008736 & -0.00592 & -0.00283 & -0.00919 & 0.008127 & -0.0035 & -0.00629 \\
\hline t Stat for Tax Index Variable & 1.223094 & -0.85036 & -0.54381 & -1.20398 & 1.833571 & -0.80888 & -2.62164 \\
\hline P-value for Tax Index Variable & 0.227265 & 0.399348 & 0.589092 & 0.234499 & 0.072922 & 0.422575 & 0.011688 \\
\hline
\end{tabular}


Notes 